\title{
Adaptive MPPT of Water Photovoltaic Pumping System Based on Vector Controlled Induction Motor Drives
}

\author{
Montaser Abd El Sattar1,", Kenawy Ahmed², Alaa AboZied³, Ahmed A. Zaki Diab,"* \\ ${ }^{1}$ Department of Electrical Engineering, Faculty of Engineering, South Valley University, Qena 83523, Egypt \\ ${ }^{2,4}$ Electrical Engineering Department, Faculty of Engineering, Minia University, Minia 61111, Egypt \\ ${ }^{3}$ Electrical Engineering Department, Faculty of Engineering, Al-Azhar University, Qena, Egypt \\ * Corresponding: Montaser Abd El Sattar (Montaser.A.Elsattar@eng.svu.edu.eg) and Ahmed A. Zaki Diab (a.diab@mu.edu.eg)
}

\begin{abstract}
In this paper, the maximum power point (MPP) of photovoltaic (PV) for vector control of an induction motor (IM) driving water is achieved. This paper implements and analyzes the maximum power point tracking (MPPT) in one stage. The vector control scheme for an induction motor has been introduced to improve the reliability of the PV system. Furthermore, the Adaptive incremental conductance (AINC) method has been applied to track the maximum power point (MPP) of the PV plant. Additionally, the principles of vector control of an induction motor are used for voltage source inverter fed induction motor pumping system. The control scheme is simulated and validated considering the environmental conditions such as solar radiation and temperature. The scheme has been validated through MATLAB/SIMULINK. The obtained results and analysis authorize that, the proposed control system is accurate and effective. In addition, the results show that, the induction motor drive is stable during dynamic and steady-state conditions.
\end{abstract}

Keywords: Photovoltaic Pumping System, MPPT, Incremental Conductance Method, AC drives, Induction Motors Drives.

\section{Nomenclature}

D Monthly average daily diffuse irradiation in $\mathrm{MJ} / \mathrm{m}^{2}$.

G, Go Monthly average daily global and extraterrestrial irradiation in $\mathrm{MJ} / \mathrm{m}^{2}$.

G/Go Clearness index.

D/G Diffuse fraction.

IM Induction Motor

PV Photovoltaic

INC Incremental Conductance

MPPT Maximum Power Point Tracking

\section{Introduction}

The water pumping framework is a strict vitality procedure. However, the preservationist pumping frameworks remain controlled from non-renewable energy sources. The expenses of non-renewable energy sources are combined and cause extra stinging to the earth with high contamination and ozone-depleting substance discharges [1-3]. As of late, sunbased vitality is utilized to give power to water pumping systems in the disengaged far-off region in numerous nations [4]. Egypt proceeds as a promising nation for creating electric vitality from the sun since it has a unique number of daylight hours lasting through the year with higher light levels [5]. The yearly varieties and pattern investigation were broke down for

Received:27October, 2020, Accepted:3 April 2021 every day worldwide, direct, and diffuse radiation on an even surface, day by day daylight term, and for the day by day proportions G/G0, and D/G for the stations Minia, Matruh, Cairo and Aswan [6]. The circulation of all parts of radiation and their proportions over Egypt's examination stations is likewise talked. The outcomes display that Egypt is described by moderately high typical normal radiation rates, both worldwide and direct, and a generally high recurrence of splendid days. Due to its urbanization and high contamination, Cairo has moderately low typical day-by-day radiation rates, especially in direct radiation, and the recurrence of brilliant days [7].

The water pumping systems dependent on the sun-based vitality are essential for improvement projects in distant zones. Furthermore, the PV pumping frameworks can support desert development and support the Egyptian economy [8]. Though, with the low productivity of the sun-powered cell, the MPPT strategies are applied to enhance the trademark of the PVs [9]. Besides, MPPT prompts to make the PV frameworks operate proficiently and successfully in various climatic circumstances. The furthermost mainstream sort of electrical machines utilized for water frameworks as DC motors and induction motors 


\section{Vol. 41, No.2. July 2022}

(IMs). Be that as it may, DC motors have numerous downsides started from habitually maintenance issues identified with the nearness of the commutators and brushes. In this way, the utilization of the pumping framework dependent on an IM is the attractive proposition with high quality, speed ability, robustness and support free activities [10, 11]. Both fieldoriented control (FOC) and direct current control (DTC) are the most important implemented controlling methods of induction motor-controlled applications due to their effectiveness and precisely in controlling process. FOC achieves a separation between the flux and torque of the motor [12, 13] to produce the optimal fast response torque and wide range of speed control. Although, it suffers from high sensitivity with respect to the changing values of motor parameters as a result of motor temperature variation especially motor drive resistances [14]. DTC technique has two main drawbacks such as existing ripples on the torque and stator flux mainly when the motor is low and highly variations of the switching frequency [14].

Also, the vector control hypothesis's utilization with induction machines outcomes in enhancing the control features for the superior applications [15]. Thus, this paper presents the PV pumping framework dependent on PV exhibit, DC capacitor, a voltage source converter, induction motor, most maximum power point (MPPT) strategy. Moreover, vector control has been applied in order to control the motor and water tank stockpiling rather than batteries.

PV is developed utilizing arrangement and equal associations of PV cells for coordinating the necessary power, voltage and current rating of the motor. At this time, the voltage source inverter (VSI) straightforwardly changes over DC capacity to AC power, without the need for DC-DC converter and erases its expense. It thusly diminishes the entire system size, as there is no requirement for an inductor. Additionally, in PV storage system, when daylight is accessible, sun-powered vitality is put away, looking like possible vitality in the water tank. Moreover, it is released in the time of high demand for electric vitality instead of utilizing battery storage structures, which are overwhelming, increasingly costly, and have a low lifetime equivalent to onefifth of that for the PV framework. So, the considerable battery banks are not prudent in this study contingent upon the recently referenced reasons [16]. Vector control can be utilized for the induction machine control, enhancing its exhibition over the scaler variable recurrence drive $[4,17,18]$. The working point, which is characterized as the purpose of convergence among the voltage-current qualities of the PV board and the attributes of the induction motor set, might be a long way from the MPP of the PV systems that prompts a significant loss of the accessible power produced by the PV modules [18, 19].

An IM in PV pumping systems has better performance than other commercial motors due to its high robustness, availability in local marks with low price and maintenance cost, and it has high efficiency [20]. Normally, a DC-DC boost converter is used to track maximum power from the PV panels with the aid of variable step size incremental conductance and employing ATMega328 microcontroller located at the Arduino Uno board [21]. Moreover, the operation of the suggestion PV system can be done without batteries to save the initial cost, repairing, and maintenance. Many types of PV water pumping stations have been reported in literature. From these proposed types is $\mathrm{PV}$ power pumping station that is equipped with an incremental conductance (INC) to track the maximum power from PV station and IM control of scalar type [21]. However, it suffers from of slowing response and high oscillations due to using INC method with fixed step size, and, also has poor speed accuracy at low motor speed [22]. In Ref. [23], an optimization genetic algorithms (GA) was employed for two MPPT algorithms which were perturb and observe and fuzzy techniques to drive permanent magnet DC (PMDC) motor. This kind of motor is not popular for water pumping and has faced of non-availability of rare earth magnet and cost constraints [24]. GA is normally used to optimize other algorithms from biological evolution [25]. However, this technique has guarantee identification of global minimum, also, it is not recommended for optimizing excessively complex or very large problems and needs much time to fine tune all parameters and achieve convergence [26].

The MPPT system has been utilized in the control scheme to enhance the working point for power extraction. That has been performed by diminishing and expanding the estimation of reference speed used to the vector control to coordinate the PV pump with the optimum motor operating point. 
In this paper, vector control drives in order to control a PV pumping system to estimate the MPP is presented. The core contributions of the presented work are to implement the single-stage MPP tracking system. Additionally, the results validate the effectiveness of the planned PV pumping system.

\section{Configuration of PV Water Pumping System}

The typical system of the PV pumping system has been introduced in Fig 1.a. While, the schematic conformation of the planned PV pumping system is revealed in Fig 1.b. The PV module, inverter (DC/AC), induction motor, and centrifugal pump are the main components of the pumping system [18].

\section{$2.1 \quad P V$ module}

The three-diode model representative process of the PV cells and modules has been applied for implementing the PV [27]. The equivalent circuit which describes the three-diode model can be introduced in Fig. 2. Firstly, the mathematical equations of the output current of the PV cell are written as [19, 27, 28]:

$I_{t}=I_{p h}-I_{d 1}-I_{d 2}-I_{d 3}-I_{s h}$

$$
\begin{aligned}
I_{t}= & I_{p h}-I_{s d 1}\left[\exp \left(\frac{q\left(V_{t}+R_{s} I_{t}\right)}{n_{1} k T}\right)-1\right] \\
& -I_{s d 2}\left[\exp \left(\frac{q\left(V_{t}+R_{s} I_{t}\right)}{n_{2} k T}\right)-1\right] \\
& -I_{s d 3}\left[\exp \left(\frac{q\left(V_{t}+R_{s} I_{t}\right)}{n_{3} k T}\right)-1\right]-\frac{V_{t}+R_{s} I_{t}}{R_{s h}}
\end{aligned}
$$

where;

$I_{d 1}, I_{d 2}$ and $I_{d 3}$ are the diode currents of $D_{1}, D_{2}$ and $D_{3}$ respectively.

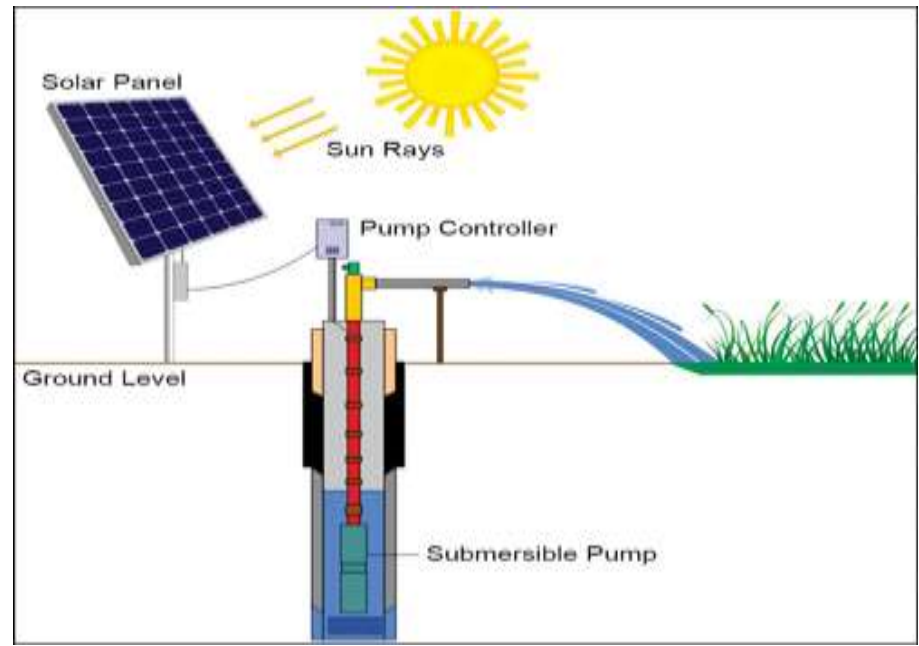

Fig. 1.a. PV pumping system; typical configuration (Courtesy: www.taiyosolar.in).

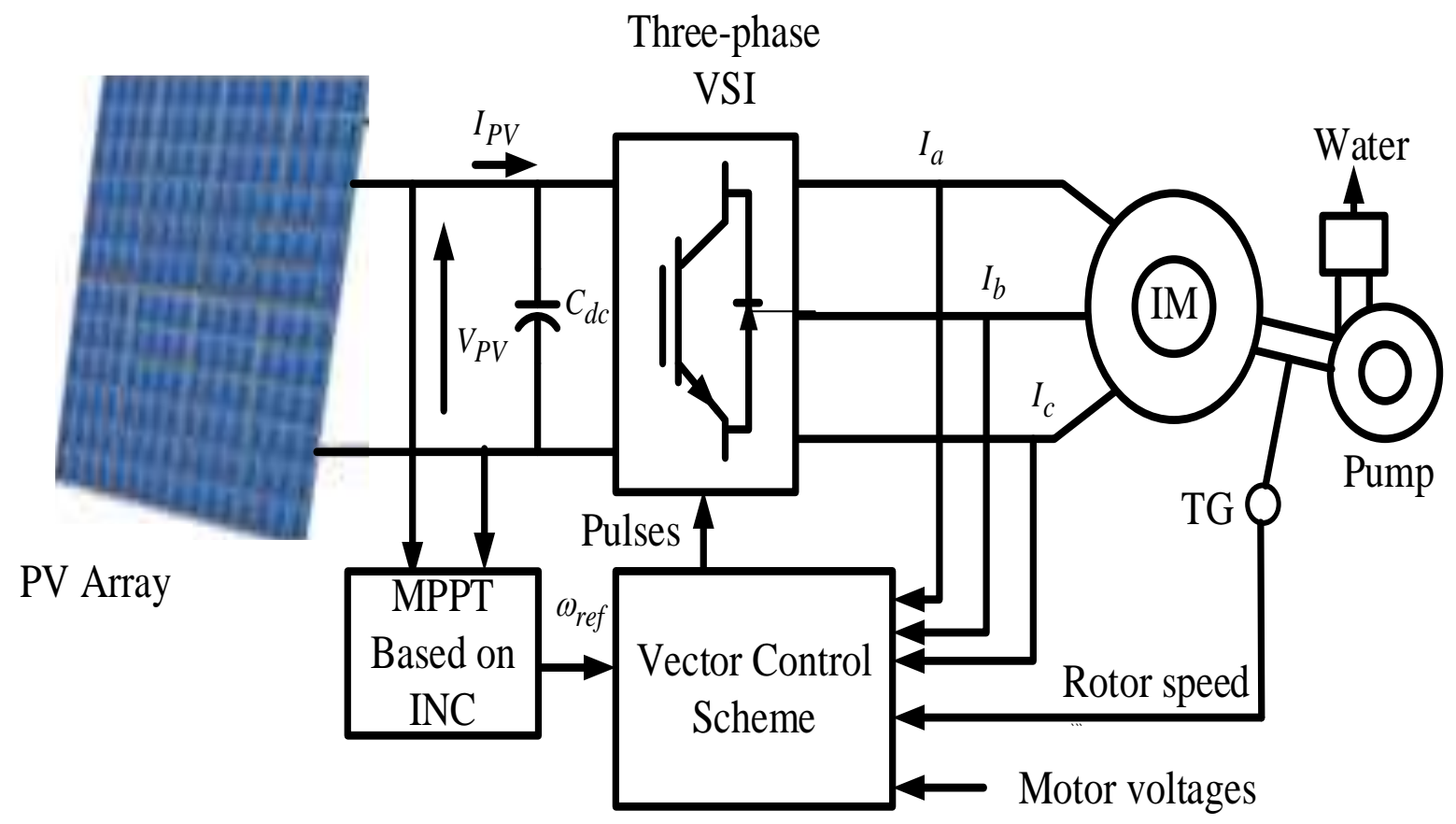

Fig. 1.b. Schematic configuration of PV pumping system. 
Vol. 41, No.2. July 2022

$I_{s d 1}, I_{s d 2}$ and $I_{s d 3}$ are the saturation currents of $D_{1}, D_{2}$ and $D_{3}$ respectively.

$n_{1}, n_{2}$ and $n_{3}$ are the ideality factors of $D_{1}, D_{2}$ and $D_{3}$ respectively.

$R_{s}, R_{\text {sh }}$ are the series and shunt resistances respectively.

Furthermore, $q$ denotes to charge magnitude on an electron as $q=1.602 * 10^{-19}$ Coulombs (C), and k denotes Boltzmann constant of $k=1.380 * 10^{-23}(J / K)$ and $T$ denotes temperature in Kelvin $(K)$.

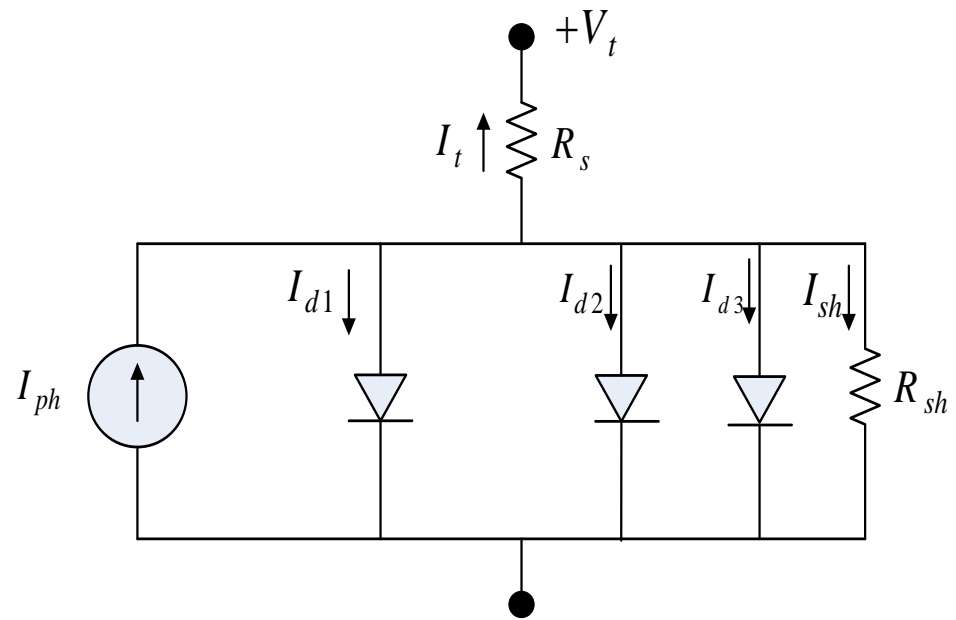

Fig. 2. Three-diode model.

An archetypal model of solar PV module considering the three-diode model has been shown in Fig. 3. The model contains numerous solar cells organized in series and/or in parallel. Such configuration is to offer the specific characteristics from the module. $N_{s}$ represents the number of series cells. Wherever $N_{p}$ represents the number of cells in parallel. The output current of PV module can be represented as:

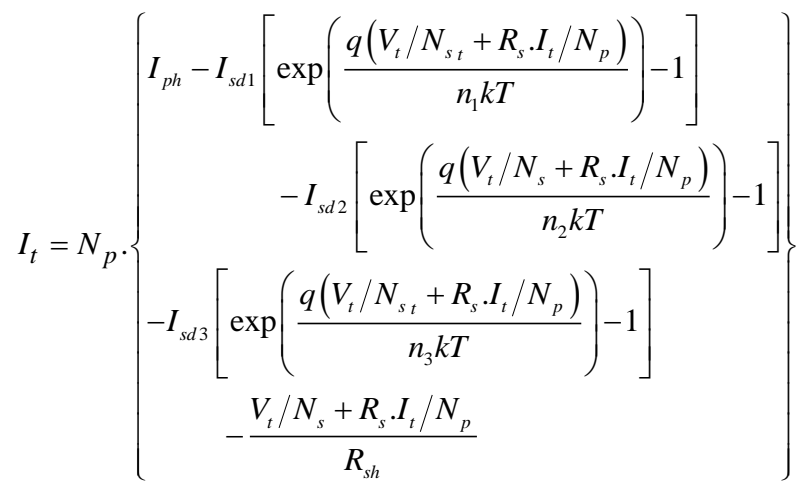

The three-diode model of the PV module contains 9unknown parameters of $\mathrm{R}_{\mathrm{S}}, \mathrm{R}_{\mathrm{sh}}, \mathrm{I}_{\mathrm{sd} 1}, \mathrm{I}_{\mathrm{sd} 2}, \mathrm{I}_{\mathrm{sd} 3}, \mathrm{I}_{\mathrm{ph}}, \mathrm{n}_{1}, \mathrm{n}_{2}$, and $\mathrm{n}_{3}$. All parameters have been extracted based on PSO optimization algorithm. Figs. (4) and (5) illustrate the results of the threediode model of the large array, which has the arrangement of $\mathrm{N}_{\mathrm{s}}$ $=35$ and $\mathrm{N}_{\mathrm{p}}=2$. Moreover, Figs. (4) and (5) display the characteristics of the PV module under variation of irradiation and temperature.

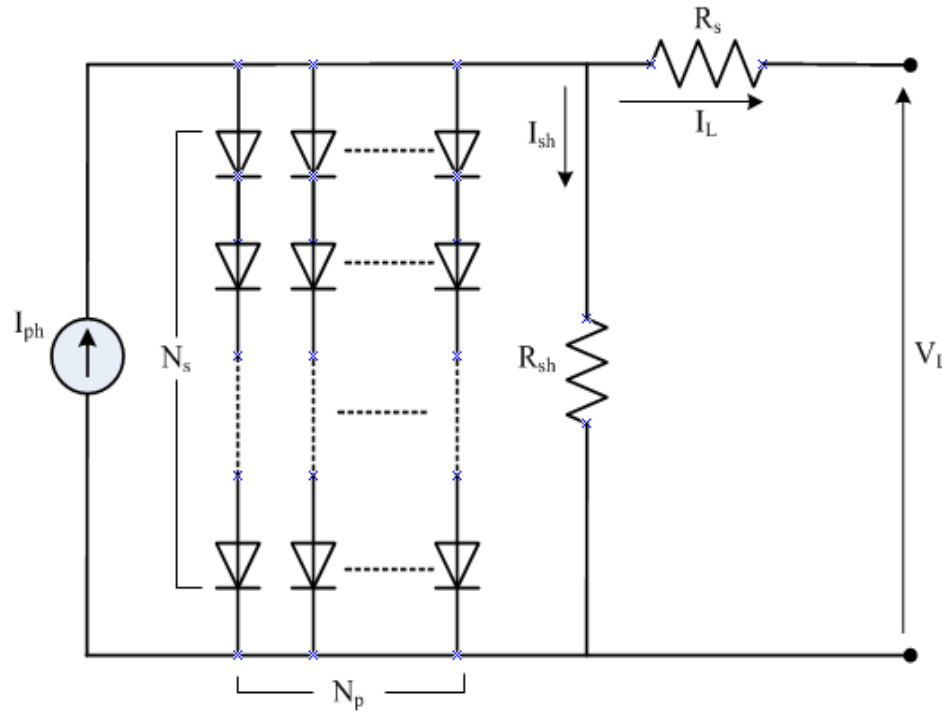

Fig. 3. Equivalent circuit of solar PV module model.

\subsection{DC-link capacitor representation}

The designed DC bus capacitor can be calculated as follows:

$C_{d c} \geq \frac{P}{2 \omega V_{d c} \Delta v_{d c}}$

where; $V_{d c}$ denotes the reference DC voltage of VSI. While $\mathrm{P}$ denotes required power. Moreover, $\omega$ denotes line angular frequency in $\mathrm{rad} / \mathrm{sec}$ while $\Delta \mathrm{v}_{\mathrm{dc}}$ denotes voltage ripple amplitude of the DC-link capacitor $[5,6]$.

Based on the data specifications which are provided in Appendix I, the designed DC bus capacitor is

$C_{d c} \geq \frac{10 * 746}{2 * 2 * p i * 50 * 600 * 1}$

$C_{d c} \geq 1.9798 \mathrm{e}-04$

Moreover, the tuning is based on trial and error with values which are more significant than $1.9798 \mathrm{e}-04 \mathrm{~F}$. The value of $3000 \mu \mathrm{F}$ gives the best results. So, the designed DC bus capacitor equals to $3000 \mu \mathrm{F}$. 
Vol. 41, No.2. July 2022
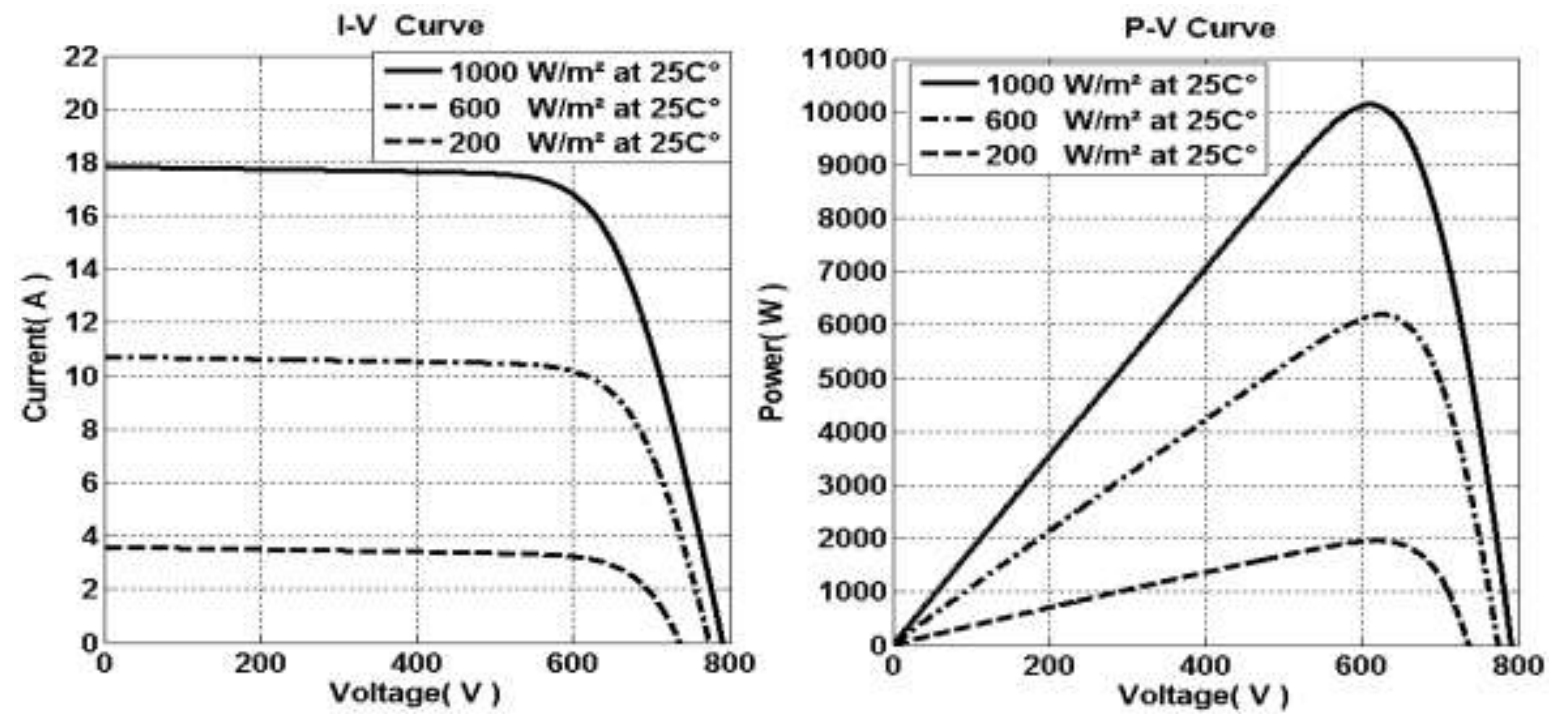

Fig. 4. PV features at $25^{\circ}$
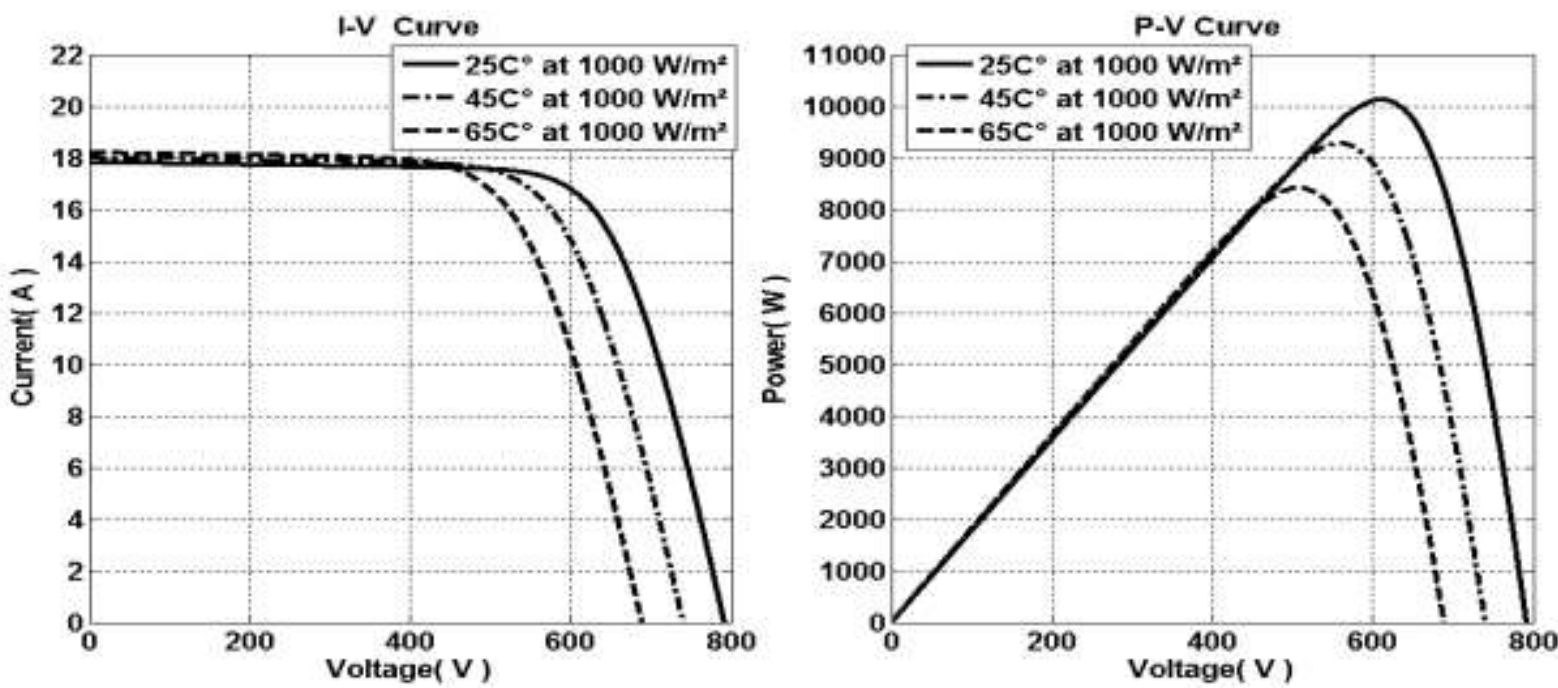

Fig. 5. PV Features at $1000 \mathrm{~W} / \mathrm{m}^{2}$

\subsection{Centrifugal pump representation}

The torque-speed features of coupled three-phase IM and centrifugal pump can be applied to estimate the mathematical representation. Additionally, torque and speed have the following characteristics [29].

$$
T_{n}=K \times \omega_{n}^{2}
$$

where; $T_{n}$ denotes the nominal torque of the induction motor. As well, $\omega_{\mathrm{n}}$ denotes the nominal speed $\mathrm{rad} / \mathrm{sec}$. The output power can be represented as follows:

$$
P_{\text {out }}=K \times \omega^{3}
$$

The pump hydraulic power necessity may be written as:

$$
P_{\text {hyd }}=g \times Q \times H \times \rho_{\text {water }}
$$

$$
P_{P V}=V \times I
$$

Moreover, the efficiency is estimated as:

$$
\eta_{\text {overall }}=\frac{P_{\text {pump }}}{P_{P V}} * 100 \%
$$

Anywhere; $g=9.81 \mathrm{~m} / \mathrm{s}^{2}$ while $\mathrm{Q}$ denotes flow quantity $\left(\mathrm{m}^{3} / \mathrm{s}\right)$. Moreover, $\mathrm{H}$ denotes Net Head $(\mathrm{m})$, and $\rho$ water denotes density of water $\left(\mathrm{kg} / \mathrm{m}^{3}\right)$.

\subsection{Induction motor model}

The mathematical model of induction motor in $\alpha-\beta$ stationary reference frame has been established through the conservative model of the 3-phase Y-connected induction motor and is denoted as [30, 31]:

The PV power is considered as: 
Vol. 41, No.2. July 2022

$p\left[\begin{array}{l}i_{s} \\ \lambda_{r}\end{array}\right]=\left[\begin{array}{ll}A_{11} & A_{12} \\ A_{21} & A_{22}\end{array}\right]\left[\begin{array}{l}i_{s} \\ \lambda_{r}\end{array}\right]+\left[\begin{array}{l}B \\ 0\end{array}\right] u_{s}$

$i_{s}=C \cdot\left[\begin{array}{c}i_{s} \\ \lambda_{r}\end{array}\right]$

Anywhere;

$i_{s}=\left[\begin{array}{ll}i_{\alpha s} & i_{\beta s}\end{array}\right]^{T}, \lambda_{r}=\left[\begin{array}{ll}\lambda_{\alpha r} & \lambda_{\beta r}\end{array}\right]^{T}, u_{s}=\left[\begin{array}{ll}V_{\alpha s} & V_{\beta s}\end{array}\right]^{T}$,

$A_{11}=-\left\{\left(\frac{R_{s}}{\sigma L_{s}}+\frac{1-\sigma}{\sigma T_{r}}\right)\right\} I$,

$A_{12}=\left\{\frac{L_{m}}{\sigma L_{s} L_{r} T_{r}}\right\} I-\left\{\frac{L_{m}}{\sigma L_{s} L_{r}} \omega\right\} J$,

$A_{21}=\left(\frac{L_{m}}{T_{r}}\right) I, A_{22}=-\left(\frac{1}{T_{r}}\right) I+\omega J, \mathrm{~B}=\left(\frac{1}{\sigma \mathrm{L}_{\mathrm{s}}}\right) \mathrm{I}$,

$C=\left[\begin{array}{ll}I & 0\end{array}\right], C_{2}=\left[\begin{array}{ll}0 & I\end{array}\right]$,

I, J denote unit matrix and skew-symmetric matrix respectively:

$I=\left[\begin{array}{ll}1 & 0 \\ 0 & 1\end{array}\right], J=\left[\begin{array}{cc}0 & -1 \\ 1 & 0\end{array}\right]$

where; $T_{e}=k_{t}\left(\lambda_{d r} i_{q s}-\lambda_{q r} i_{d s}\right)$ and $k_{t}=\frac{3 n p L_{m}}{4 L_{r}}$

\section{Control System Analysis}

Adaptive Incremental Conductance (AINC) has been used for determining the MPPT. Furthermore, the field-oriented control (FOC) is functional for decupling the flux and torque control loops of the IMs [14]. Moreover, the MPPT process has been applied to guess the reference speed according to the MPPT. The command speed has been considered to be the reference of the FOC scheme.

\subsection{Adaptive incremental conductance (AINC)}

Many MPPT algorithms have been proposed in the last decade [32]. The algorithms included the conventional methods such as $\mathrm{P} \& \mathrm{O}$ and Incremental Conductance (INC) [33]. Moreover, the optimization algorithms have been applied for MPPT [34, 35]. Furthermore, AI has been employed for the same purpose. However, the application of these various algorithms with the application of pumping systems needs more interest. In this paper, the AINC algorithm has been implemented with the required modification to apply for such a case of the pumping system. The AINC considers the rate change of the power-voltage curve of the PV system. At the desired MPPT the slope is null.

In contrast, the power-voltage curve slope is negative in the right-side of the desired PV MPP. Furthermore, a positive slope of the power-voltage curve on the left side of the desired PV MPP. The overall process of the AINC has been displayed in Fig. 6 [6]. The mathematical representation of the AINC can be described as follows:

$P=V \times I$

and,

$\frac{d P}{d V}=\frac{I}{V}+\frac{d I}{d V}$

The null slope of the P/V curve at the MPP can be defined as:

$\left.\frac{d P}{d V}\right|_{M P P}=\frac{I}{V}+\frac{d I}{d V}=0$

At any point $\mathrm{n}$ the $\mathrm{P} / \mathrm{V}$ curve can be represented as:

$\frac{d I}{d V}=\frac{-I}{V}$

Consequently, in the conventional PV system, the feature had been taken as the voltage or the duty cycle in the DC/DC converter case. In this paper, the changing of the reference rotor speed has been selected to extract the MPP. The flowchart of the MPPT technique has been revealed in Fig. 6. The reference speed tracked by the MPPT has been feed to the VCIM drive to regulate the motor operation at this speed to ensure extracting the MPP from the PV pumping system.

\subsection{Vector control on induction motor}

The VCIM drive has been applied for controlling IM. The reference torque $T_{e}^{*}$ is a control signal from the PI regulator can be represented as [36]:

$T_{e}^{*}=K_{p} e+K_{i} \int e d t$

where; $K_{p}, K_{i}$ denote parameters of the PI controller and error $(\mathrm{e})=$ $\omega_{\text {ref }}-\omega_{r}$

The reference stator current of $I_{q S}^{*}$ is estimated as:

$I_{q s}^{*}=\frac{4 \times L_{r}}{3 \times P \times L_{m} \times \lambda_{r}} \times T_{e}^{*}$

where; $\mathrm{L}_{\mathrm{r}}$ denotes the inductance of the rotor winding. Moreover, the $\mathrm{P}$ denotes poles number. While the $\mathrm{L}_{\mathrm{m}}$ denotes mutual inductance. The symbol of $\lambda_{\mathrm{r}}$ denotes rotor flux which can mathematically be represented as:

$\lambda_{r}=\frac{L_{m} \cdot I_{d s}}{1+T_{r} \cdot s}$

where; $T_{r}=L_{r} / R_{r}$ denotes rotor time constant while $R_{r}$ denotes rotor resistance. The symbol $\mathrm{I}_{\mathrm{ds}}$ denotes d-axis current component. Moreover, $I_{d s}^{*}$ denotes corresponding d-axis current to the rotor 
flux $\lambda_{r}^{*}$; through the following mathematical equation:

$I_{d s}^{*}=\lambda_{r}^{*} / L_{m}$

The rotor-field angle $\theta_{\mathrm{e}}$ is essential for Park and may be estimated as:

$\theta_{e}=\int\left(\omega_{m}+\omega_{s l}\right) d t$

The slip frequency has been estimated as:

$\omega_{s l}=\frac{L_{m} \times R_{r}}{l_{r} \times L_{r}} \times I_{q s}$

The $I_{q s}^{*}$ and $I_{d s}^{*}$ current have been transformed to $I_{a}^{*}, I_{b}^{*}$ and $I_{c}^{*}$.

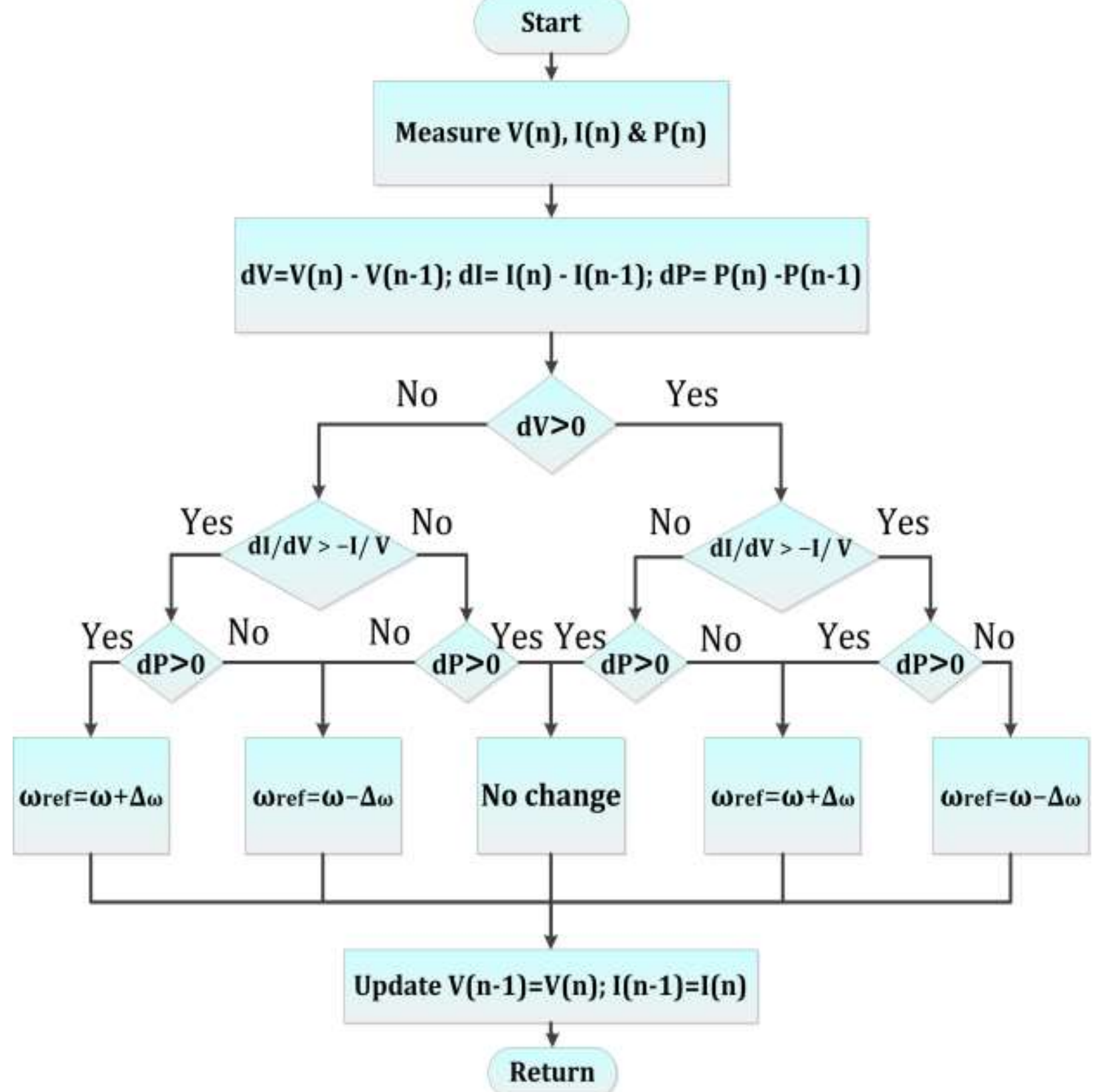

Fig. 6. Adaptive INC for MPPT based on rotor speed regulating. inputs to hysteresis comparator $[37,38]$. The electromagnetic torque is defined as [9]:

$$
T_{e}=k_{t}\left(\lambda_{d r} i_{q s}-\lambda_{q r} i_{d s}\right)
$$

where; $k_{t}$ denotes torque constant of:

$k_{t}=3 n p L_{m} / 4 L_{r}$,

so, the electromagnetic torque considering the principles of VCIM is represented as:

$T_{e}=K_{T} i_{q s}$, where $K_{T}=k_{t} L_{m} i_{d s}$ 
Vol. 41, No.2. July 2022

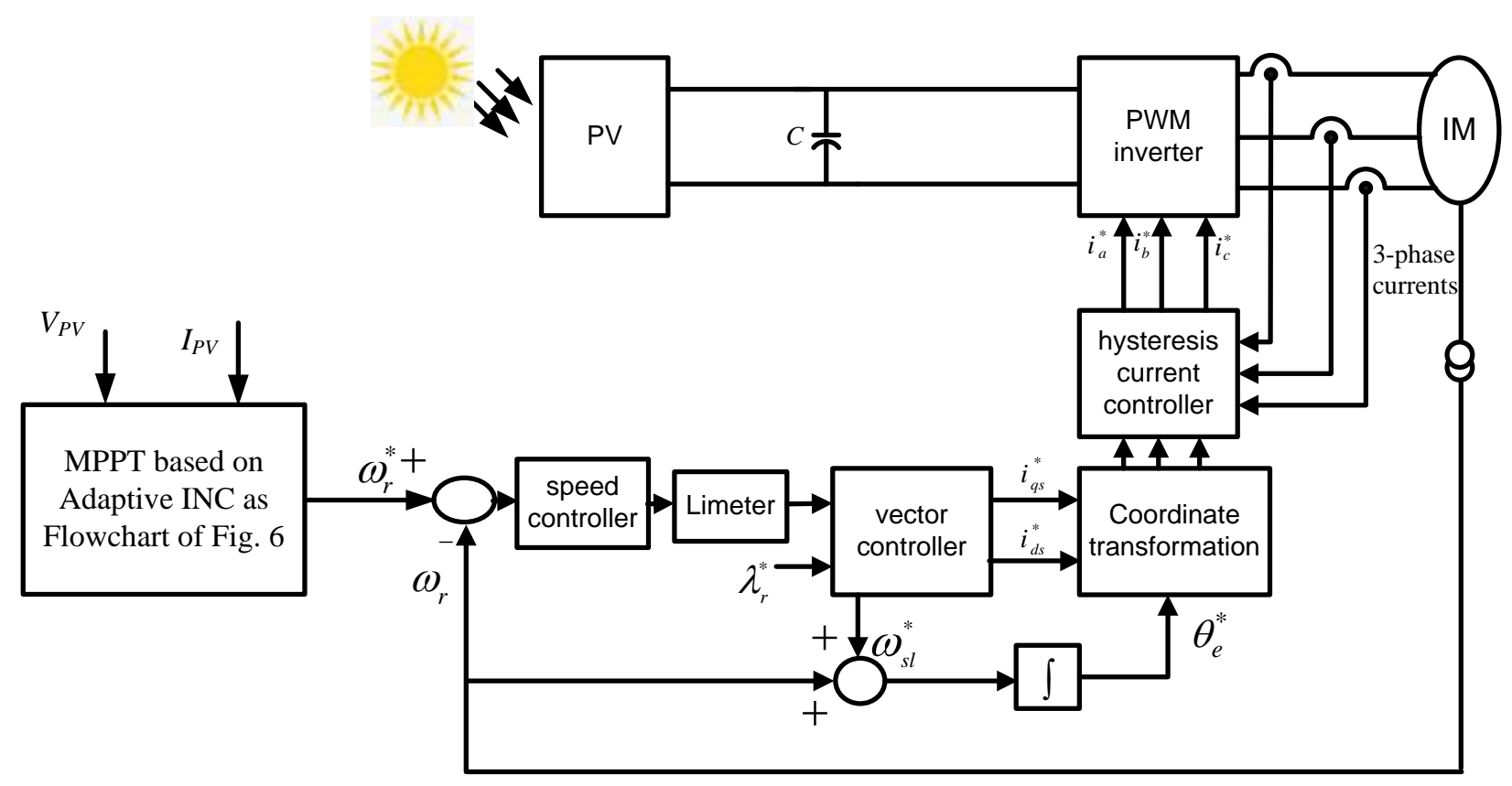

Fig. 7.a. Complete block diagram of the PV pumping system.

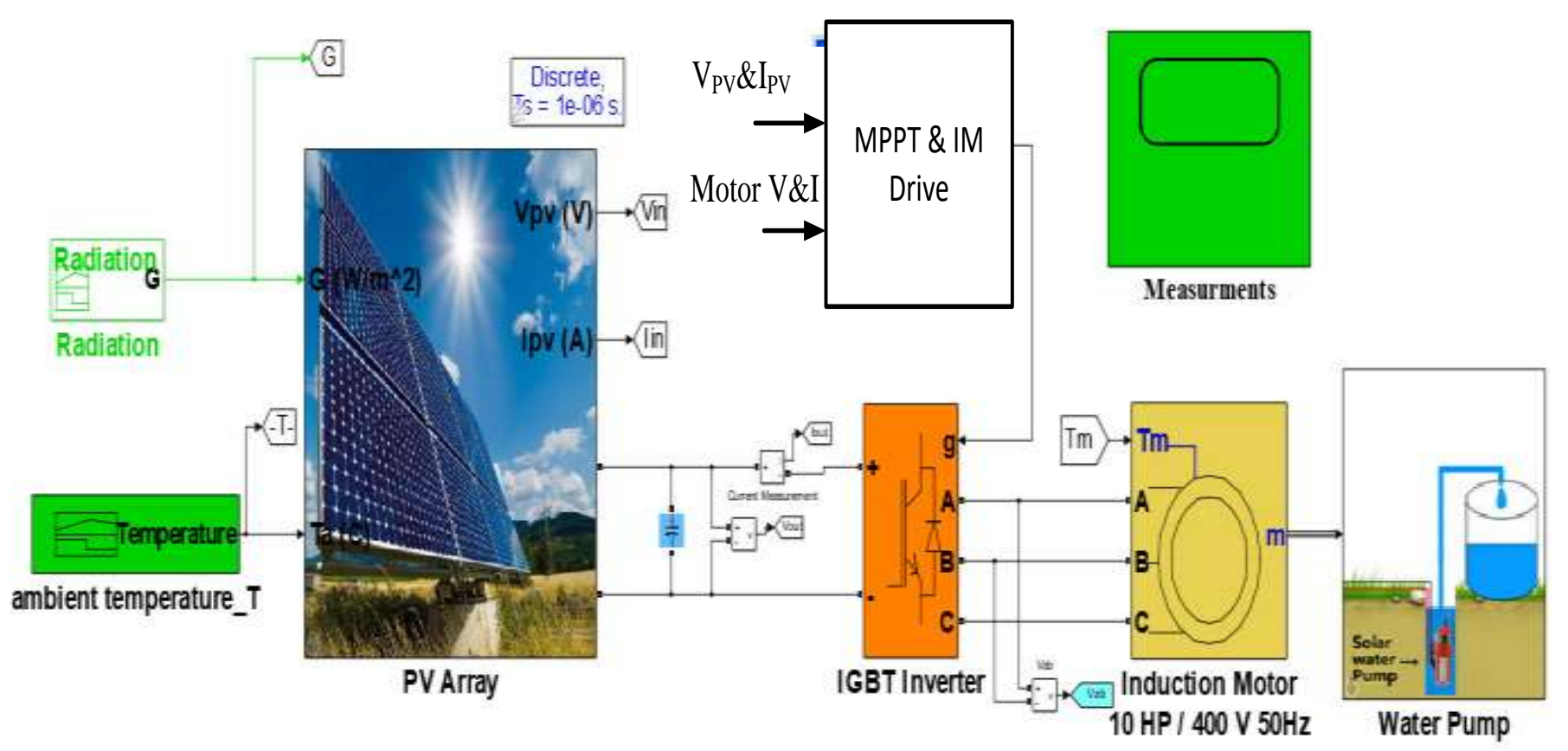

Fig. 7.b. Configuration of the PV pumping system.

\section{Simulation Results}

Figure 7.a shows the block diagram of the designed PV pumping system. Moreover, Fig. 7.b shows the proposed Simulink configuration of the overall system. The system has been tested and evaluated based on Matlab/Simulink. The water tank will save the amount of excess (surplus) water. The system tests have occurred considering the variations of the solar radiation $(\mathrm{G})$ and ambient temperature $(\mathrm{T})$.

The module data of the PV simulator considering the threediode model at $25^{\circ} \mathrm{C}, \mathrm{AM} 1.5$, and $1000 \mathrm{~W} / \mathrm{m}^{2}$ has been found in
Appendix I. Furthermore, The PV array design values at STC have been listed in Appendix I. Also, in this paper, for the PV water pumping system, the induction motor is coupled with the pump, is capable of supplying a daily average of $47 \mathrm{~m}^{3} / \mathrm{hr}$ of water at a head of 30m [39], where its parameters have been reported in Appendix I. The sample time is 1e-6 second as indicated from Fig. 7 may be different in the practical implementation of the control system.

The demonstration of the PV pumping system has been introduced; in starting period, steady-state, and under variation of solar radiation considering the simulated results. The obtained results demonstrate that, the system achieves fairly satisfactorily. 
Vol. 41, No.2. July 2022

Two cases of study have been included in this paper to evaluate the PV pumping system.

\section{Case 1: PV pumping system performance with the variation of the irradiance}

In this case of study, the temperature has been assumed to be at its default of $25^{\circ} \mathrm{C}$. While the solar irradiance has been varied at $1.5 \mathrm{sec}$ from $1000 \mathrm{~W} / \mathrm{m}^{2}$ to $600 \mathrm{~W} / \mathrm{m}^{2}$. The expected results if the system is accurately operated are the PV power is $10 \mathrm{~kW}$ at 1000 $\mathrm{W} / \mathrm{m}^{2}$ and $6 \mathrm{~kW}$ at $600 \mathrm{~W} / \mathrm{m}^{2}$, respectively, as shown in Fig. 4. The results of such a case of study have been displayed in Fig. 8 and Fig. 9. These figures show that, the system can be accurately extracting the MPP of the PV module. Moreover, figures show the speed, torque, and currents of the induction motor.

To analyze the performance of the induction motor drive, the $\mathrm{d}$-axis and q-axis flux have been displayed in Fig. 10. The vector control principles have been proved from the figure with the d-axis rotor flux be located at zero based on the $90^{\circ}$ between the two components in the stationary reference frame.

Table 1 lists the analysis of the results according to such case of study. From this table, at normal operating conditions, the power of the PV is $10 \mathrm{~kW}$ in the first period of simulation. While the power of the PV at the second period of the simulation time is $6.220 \mathrm{~kW}$ when the irradiance was $600 \mathrm{~W} / \mathrm{m}^{2}$.

Table 1 Analysis of the obtained PV power considering the variation of the irradiance.

\begin{tabular}{|c|c|c|c|}
\hline TIME & $\begin{array}{c}\text { TEMPERATURE } \\
\left({ }^{\circ} \mathbf{C}\right)\end{array}$ & $\begin{array}{c}\text { IRRADIANCE } \\
\left(\mathbf{W} / \mathbf{m}^{2}\right)\end{array}$ & $\begin{array}{c}\text { Extracted } \\
\mathbf{P V} \text { power } \\
(\mathbf{k W})\end{array}$ \\
\hline $\mathbf{0 . 5} \mathrm{sec}$ to $1.5 \mathrm{sec}$ & 25 & 1000 & 10 \\
\hline $\mathbf{1 . 5} \mathbf{s e c}$ to $3 \mathrm{sec}$ & 25 & 600 & 6.220 \\
\hline
\end{tabular}
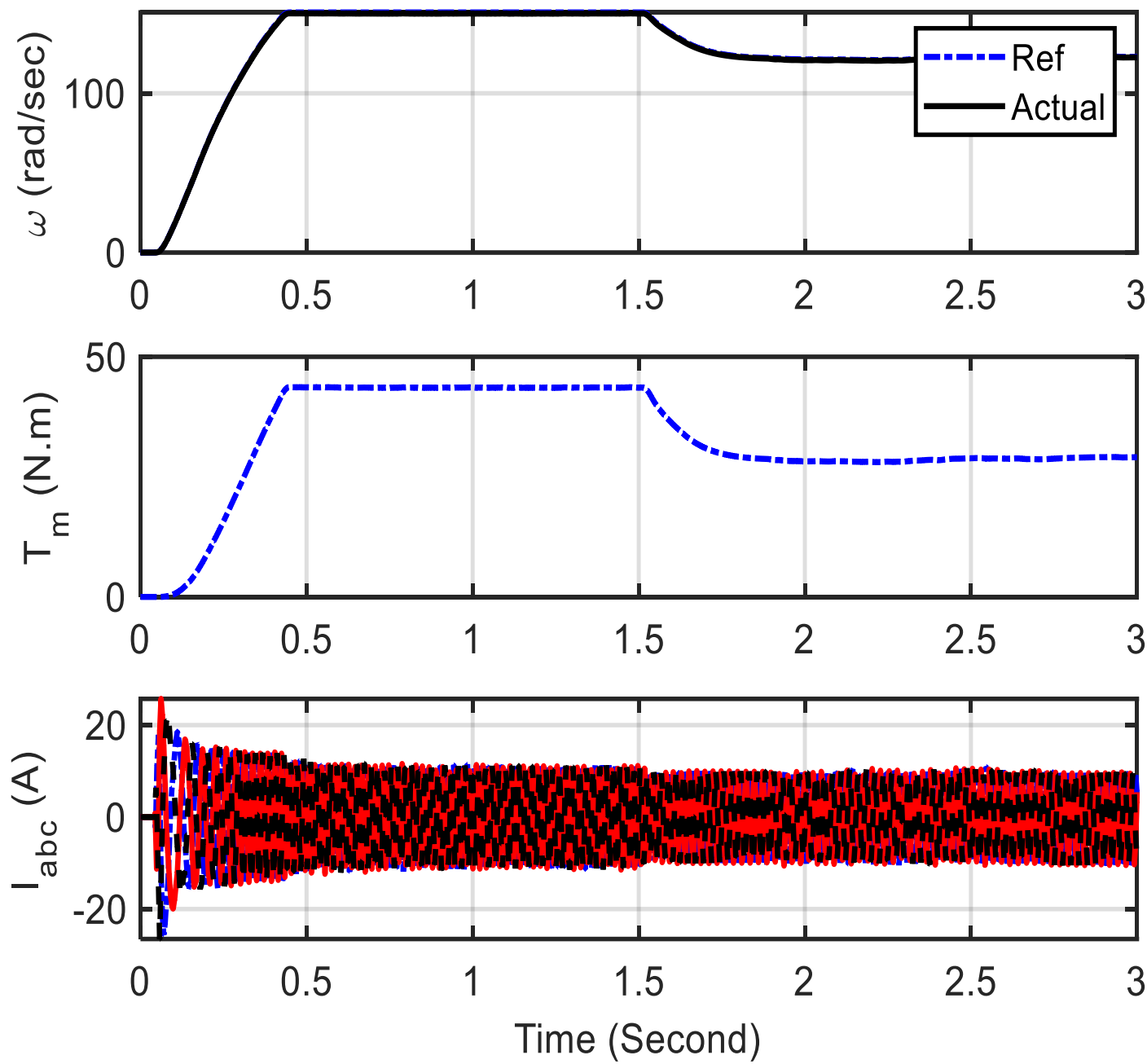

Fig. 8. The features of the PV pumping system considering irradiance variation respecting the speed, torque and currents of induction motor. 
Vol. 41, No.2. July 2022
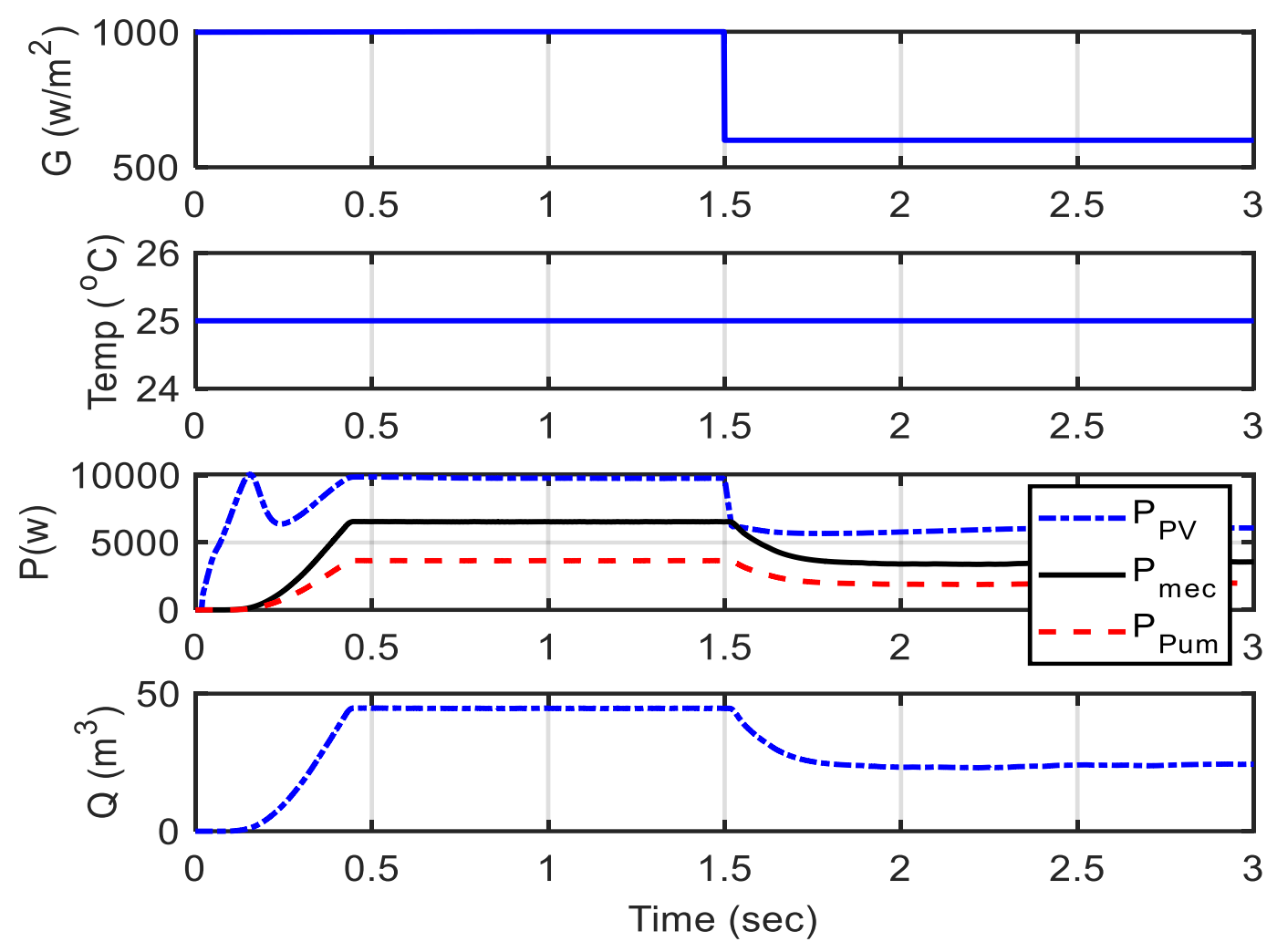

Fig. 9. The features of the PV pumping system considering irradiance variation.

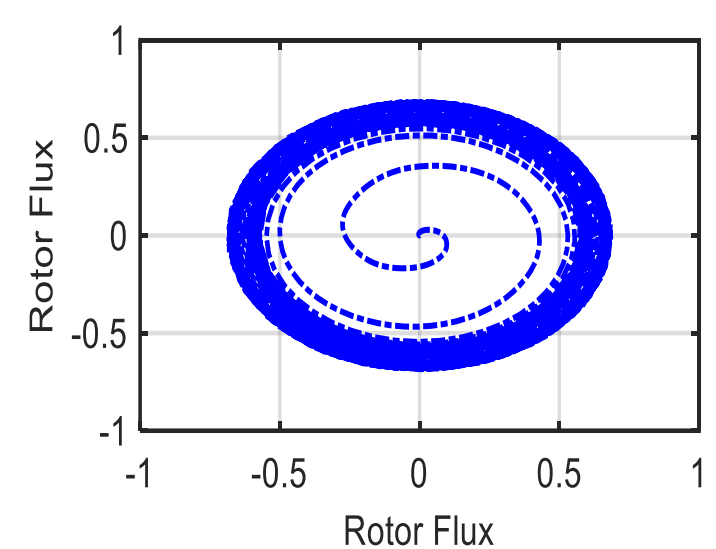

a)

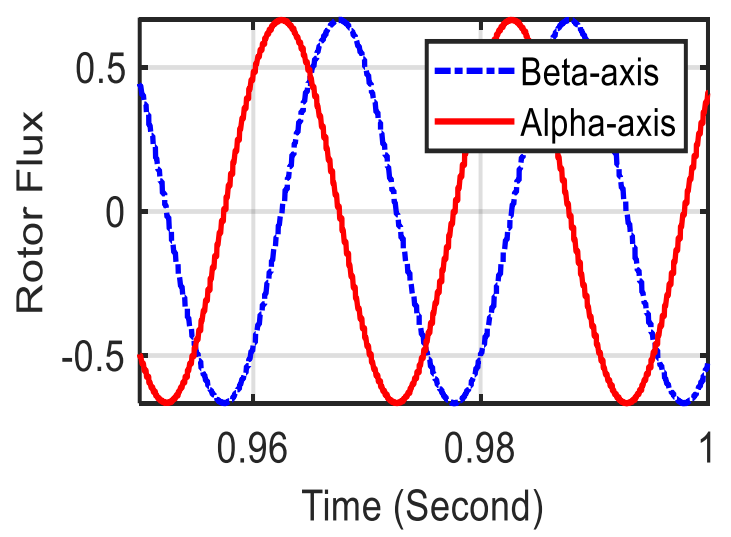

b)

Fig. 10. The features of vector control drive for PV pumping system considering irradiance variation; rotor flux in the stationary reference frame.
Case 2: PV pumping system performance with Temperature variation and irradiance variation

In this case of study, the temperature has been varied from $25^{\circ} \mathrm{C}$ to $65^{\circ} \mathrm{C}$ at $1.5 \mathrm{sec}$ and then will be changed to $25^{\circ} \mathrm{C}$ at $2.5 \mathrm{sec}$. the irradiance has been assumed to vary from $1000 \mathrm{~W} / \mathrm{m}^{2}$ to 600 $\mathrm{W} / \mathrm{m}^{2}$ at $2.5 \mathrm{sec}$. For such case of study, the MPP of the PV is $10 \mathrm{~kW}$ while it equals $8 \mathrm{~kW}$ which corresponding the $25^{\circ} \mathrm{C}$ during the first 1.5 and $65^{\circ} \mathrm{C}$ from $1.5 \mathrm{sec}$. to $2.5 \mathrm{sec}$., respectively. The results of such a case of study have been illustrated in Fig. 11 and Fig.12. Figure 11 displays that, the system can be operated at the MPP at both temperatures and irradiance. These figures show the currents and voltages of the DC an AC sides. The current is also sinusoidal. Moreover, the vector control drive performance has been examined in Fig. 13. This figure validates the precision control system of the PV pumping system.

Table 2 lists the analysis of the results according to case 2 of the study. From this table at normal operation conditions, the PV's power is $10 \mathrm{~kW}$ in the first period of simulation. While the power of the PV at the second period of the simulation time is $9.1 \mathrm{~kW}$ when the irradiance was $1000 \mathrm{~W} / \mathrm{m}^{2}$ and temperature of $65^{\circ} \mathrm{C}$. However, the variation of the temperature and irradiance at the same time as $2.5 \mathrm{sec}$ for this case of study affects the accuracy of 
Vol. 41, No.2. July 2022

MPPT. It should be noted that, this assumption of variation of the temperature and irradiance at the same time is a serve changing and assumed only to test the system, but in the real-time operation, the variation of the temperature and irradiance are gradually slow random variations.
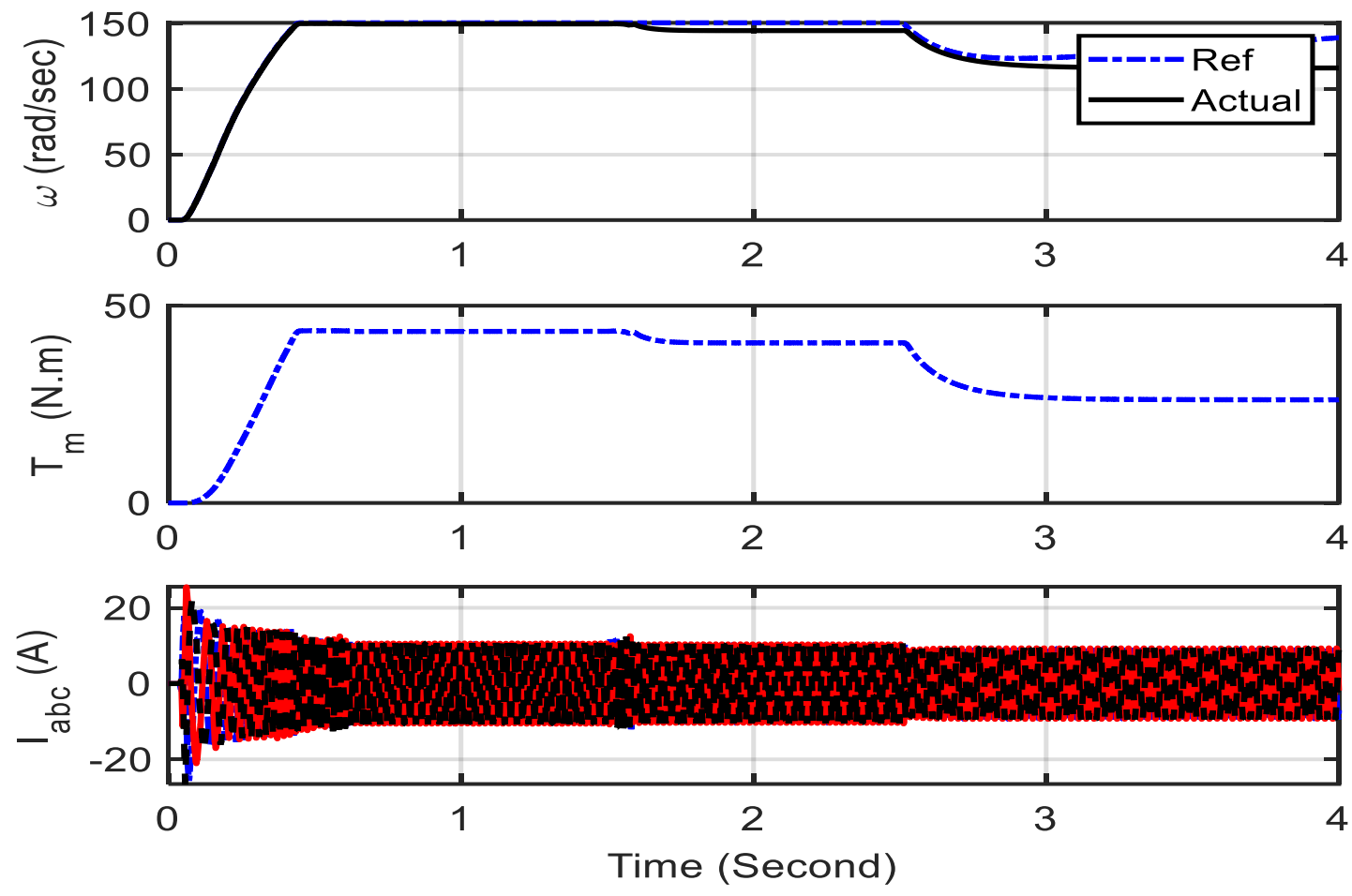

Fig. 11. The features of the PV pumping system considering the temperature variation.
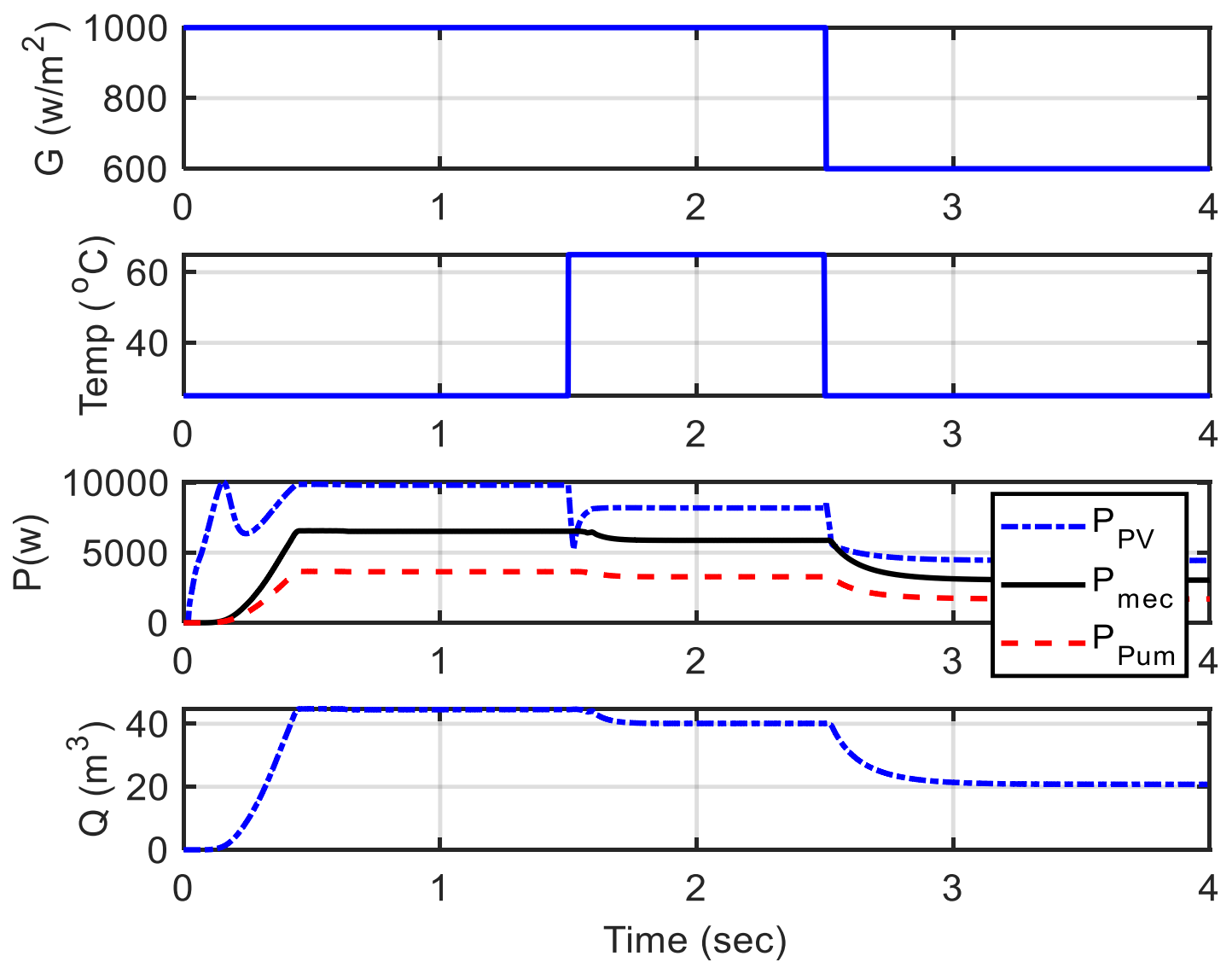

Fig. 12. The characteristics of the system considering the temperature variation. 


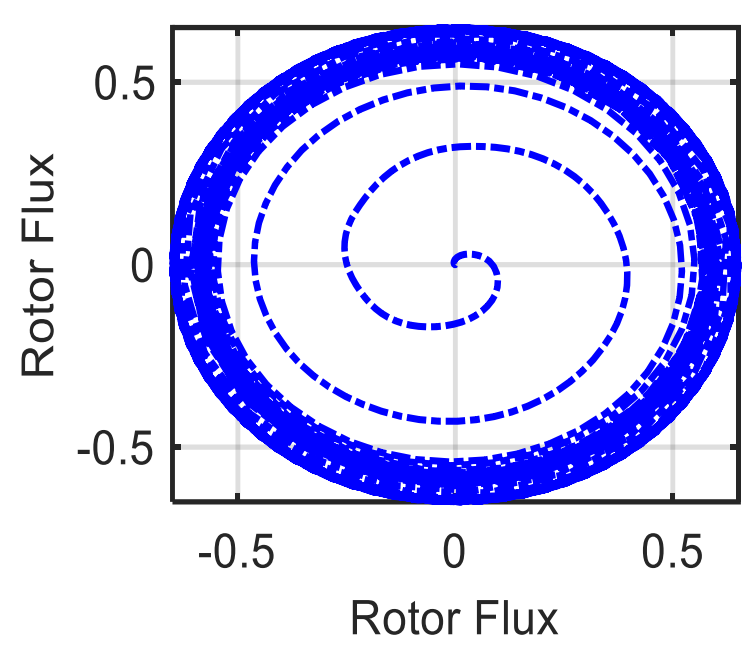

a)

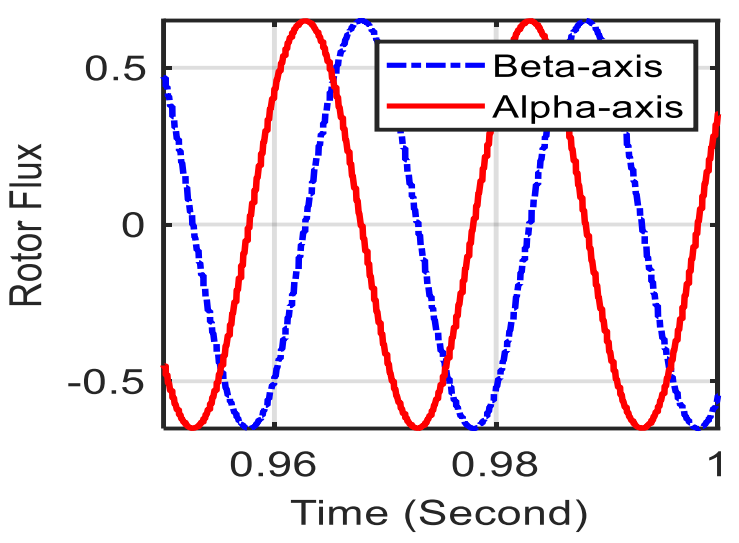

b)

Fig. 13. The features of vector control drive for PV pumping system considering temperature variation; rotor flux in stationary reference frame.

Table 2 analysis of the obtained PV power considering the variation of the irradiance and temperature.

\begin{tabular}{|c|c|c|c|}
\hline Time & $\begin{array}{c}\text { Temperature } \\
\left({ }^{\circ} \mathbf{C}\right)\end{array}$ & $\begin{array}{c}\text { Irradiance } \\
\left(\mathbf{W} / \mathbf{m}^{2}\right)\end{array}$ & $\begin{array}{c}\text { Extracted } \\
\mathbf{P V} \text { power } \\
(\mathbf{k W})\end{array}$ \\
\hline $\begin{array}{c}\mathbf{0 . 5} \mathbf{~ s e c ~ t o} \\
\mathbf{1 . 5} \mathbf{s e c}\end{array}$ & 25 & 1000 & 10 \\
\hline $\begin{array}{c}\mathbf{1 . 5} \mathbf{s e c} \text { to } \\
\mathbf{2 . 5} \mathrm{sec}\end{array}$ & 65 & 1000 & 9.1 \\
\hline $\begin{array}{c}\mathbf{2 . 5} \mathbf{s e c} \text { to } \\
\mathbf{4} \mathbf{s e c}\end{array}$ & 25 & 600 & 6.12 \\
\hline
\end{tabular}

\section{Conclusion}

The rule of vector control has been applied for the PV water pumping system in this paper. The adaptive incremental conductance (AINC) based MPPT algorithm is utilized for the estimation of MPP. Besides, the vector control approach has been utilized to drive the induction motor. The proposed configuration could be utilized in farming irrigation under any working state of shifting nature of sunlight-based irradiances and temperatures. Evaluation tests have been performed to assess the proposed PV pumping framework. The results approve the proposed development and its features. In addition, the presentation of induction motor drive is agreeable during dynamic and steady-state conditions. As the vector control has the disadvantages of complex implementation due to the axes transformation and parameter sensitivity which is considered the limitations of the presented control scheme, future work is planned to improve the presented scheme and eliminate the speed sensor. Moreover, other control methods can be applied, such as direct torque control and intelligent-based controllers. Furthermore, in future work, the MPPT considering partial shading conditions will be considered. Additionally, the predictive control algorithms of the IM drives should be implemented.

\section{References}

[1] M. E. Ropp and S. Gonzalez, "Development of a MATLAB/Simulink Model of a Single-Phase GridConnected Photovoltaic System," IEEE Transactions on Energy Conversion, vol. 24, no. 1, pp. 195-202, 2009/03 2009, doi: 10.1109/tec.2008.2003206.

[2] J. Hill, P. Chance, and S. Scherz, "NREA Annual Convention," The Rural Educator, vol. 34, no. 2, 2018/11/15 2018, doi: 10.35608/ruraled.v34i2.402.

[3] A. A. Z. Diab, H. M. Sultan, and O. N. Kuznetsov, "Optimal sizing of hybrid solar/wind/hydroelectric pumped storage energy system in Egypt based on different meta-heuristic techniques," Environmental Science and Pollution Research, pp. 1-23, 2019.

[4] A. A. Z. Diab, A.-H. M. Al-Sayed, H. H. Abbas Mohammed, and Y. S. Mohammed, "Sensorless Vector Control for Photovoltaic Array Fed Induction Motor Driving Pumping System," in SpringerBriefs in Electrical and Computer Engineering, ed: Springer Singapore, 2020, pp. 33-48.

[5] A. A. Z. Diab, "Implementation of a novel full-order observer for speed sensorless vector control of induction motor drives," Electrical Engineering, vol. 99, no. 3, pp. 907-921, 2016/10/19 2016, doi: 10.1007/s00202-016-0453-7.

[6] A. A. Z. Diab, "Real-Time Implementation of FullOrder Observer for Speed Sensorless Vector Control of Induction Motor Drive," Journal of Control, 
Automation and Electrical Systems, vol. 25, no. 6, pp. 639-648, 2014/09/09 2014, doi: 10.1007/s40313-0140149-z.

[7] H. M. B. Metwally and W. R. Anis, "Performance analysis of PV pumping systems using switched reluctance motor drives," Energy Conversion and Management, vol. 38, no. 1, pp. 1-11, 1997/01 1997, doi: 10.1016/0196-8904(95)00355-x.

[8] N. Hamrouni, M. Jraidi, and A. Chérif, "Theoretical and experimental analysis of the behaviour of a photovoltaic pumping system," Solar Energy, vol. 83, no. 8, pp. 1335-1344, 2009/08 2009, doi: 10.1016/j.solener.2009.03.006.

[9] N. Mohan, "Advanced Electric Drives," ed: John Wiley \& Sons, Inc., 2014.

[10] D. Casadei, F. Profumo, G. Serra, and A. Tani, "FOC and DTC: two viable schemes for induction motors torque control," IEEE Transactions on Power Electronics, vol. 17, no. 5, pp. 779-787, 2002/09 2002, doi: 10.1109/tpel.2002.802183.

[11] B. Bose, "Power Electronics and AC Machine Drives Advances and Trends," presented at the 2006 IEEE International Power Electronics Congress, 2006/10, 2006. [Online]. Available: http://dx.doi.org/10.1109/ciep.2006.312138.

[12] M. Errouha, A. Derouich, S. Motahhir, and O. Zamzoum, "Optimal Control of Induction Motor for Photovoltaic Water Pumping System," Technology and Economics of Smart Grids and Sustainable Energy, vol. 5, no. 1, 2020/02/19 2020, doi: 10.1007/s40866-0200078-9.

[13] S. Rafa, A. Larabi, L. Barazane, M. Manceur, N. Essounbouli, and A. Hamzaoui, "Implementation of a new fuzzy vector control of induction motor," ISA Transactions, vol. 53, no. 3, pp. 744-754, 2014/05 2014, doi: 10.1016/j.isatra.2014.02.005.

[14] I. M. Alsofyani and N. R. N. Idris, "A review on sensorless techniques for sustainable reliablity and efficient variable frequency drives of induction motors," Renewable and Sustainable Energy Reviews, vol. 24, pp. 111-121, 2013/08 2013, doi: 10.1016/j.rser.2013.03.051.

[15] B. Subudhi and R. Pradhan, "A Comparative Study on Maximum Power Point Tracking Techniques for Photovoltaic Power Systems," IEEE Transactions on Sustainable Energy, vol. 4, no. 1, pp. 89-98, 2013/01 2013, doi: 10.1109/tste.2012.2202294.

[16] N. Rebei, A. Hmidet, R. Gammoudi, and O. Hasnaoui, "Implementation of photovoltaic water pumping system with MPPT controls," Frontiers in Energy, vol. 9, no. 2, pp. 187-198, 2015/05/20 2015, doi: 10.1007/s11708015-0359-5.

[17] C.-t. Sah, R. Noyce, and W. Shockley, "Carrier Generation and Recombination in P-N Junctions and PN Junction Characteristics," Proceedings of the IRE, vol. 45, no. 9, pp. 1228-1243, 1957/09 1957, doi: 10.1109/jrproc.1957.278528.

[18] K. Ishaque, Z. Salam, and Syafaruddin, "A comprehensive MATLAB Simulink PV system simulator with partial shading capability based on twodiode model," Solar Energy, vol. 85, no. 9, pp. 22172227, 9// 2011, doi: http://dx.doi.org/10.1016/j.solener.2011.06.008.
[19] I. Kashif, S. Zainal, and T. Hamed, "Accurate MATLAB Simulink PV System Simulator Based on a Two-Diode Model," (in English), JOURNAL OF POWER ELECTRONICS, vol. 11, no. 2, pp. 179-187, 2011.

[20] B. Singh, U. Sharma, and S. Kumar, "Standalone Photovoltaic Water Pumping System Using Induction Motor Drive With Reduced Sensors," IEEE Transactions on Industry Applications, vol. 54, no. 4, pp. 3645-3655, 2018/07 2018, doi: 10.1109/tia.2018.2825285.

[21] S. Motahhir, A. El Hammoumi, and A. El Ghzizal, "The most used MPPT algorithms: Review and the suitable low-cost embedded board for each algorithm," Journal of Cleaner Production, vol. 246, p. 118983, 2020/02 2020, doi: 10.1016/j.jclepro.2019.118983.

[22] S. Motahhir, A. El Ghzizal, S. Sebti, and A. Derouich, "Modeling of Photovoltaic System with Modified Incremental Conductance Algorithm for Fast Changes of Irradiance," International Journal of Photoenergy, vol. 2018, pp. 1-13, 2018, doi: 10.1155/2018/3286479.

[23] A. A. S. Mohamed, A. Berzoy, and O. Mohammed, "Optimized-fuzzy MPPT controller using GA for standalone photovoltaic water pumping system," presented at the IECON 2014 - 40th Annual Conference of the IEEE Industrial Electronics Society, 2014/10, 2014. [Online]. Available:

http://dx.doi.org/10.1109/iecon.2014.7048809.

[24] R. Rai, S. Shukla, and B. Singh, "Sensorless Field Oriented ISMCC For Solar PV Based Induction Motor Drive For Water Pumping," presented at the 2019 IEEE International Conference on Environment and Electrical Engineering and 2019 IEEE Industrial and Commercial Power Systems Europe (EEEIC / I\&CPS Europe), 2019/06, 2019. [Online]. Available: http://dx.doi.org/10.1109/eeeic.2019.8783972.

[25] Z. Salam, J. Ahmed, and B. S. Merugu, "The application of soft computing methods for MPPT of PV system: A technological and status review," Applied Energy, vol. 107, pp. 135-148, 2013/07 2013, doi: 10.1016/j.apenergy.2013.02.008.

[26] M. A. Hannan, J. A. Ali, A. Mohamed, and A. Hussain, "Optimization techniques to enhance the performance of induction motor drives: A review," Renewable and Sustainable Energy Reviews, vol. 81, pp. 1611-1626, 2018/01 2018, doi: 10.1016/j.rser.2017.05.240.

[27] K. Ishaque, Z. Salam, and H. Taheri, "Modeling and simulation of photovoltaic (PV) system during partial shading based on a two-diode model," Simulation Modelling Practice and Theory, vol. 19, no. 7, pp. 1613-1626, 2011.

[28] A. A. Z. Diab and H. Rezk, "Global MPPT based on flower pollination and differential evolution algorithms to mitigate partial shading in building integrated PV system," Solar Energy, vol. 157, pp. 171-186, 2017.

[29] A. A. Z. Diab, A.-H. M. Al-Sayed, H. H. A. Mohammed, and Y. S. Mohammed, Development of Adaptive Speed Observers for Induction Machine System Stabilization. Springer, 2020.

[30] A. A. Z. Diab, A.-H. M. Al-Sayed, H. H. A. Mohammed, and Y. S. Mohammed, "Sensorless Vector Control for Photovoltaic Array Fed Induction Motor Driving Pumping System," in Development of Adaptive 
Speed Observers for Induction Machine System Stabilization: Springer, 2020, pp. 33-48.

[31] S. A. Mohamed and M. Abd El Sattar, "A comparative study of $\mathrm{P} \& \mathrm{O}$ and INC maximum power point tracking techniques for grid-connected PV systems," SN Applied Sciences, vol. 1, no. 2, p. 174, 2019.

[32] M. A. Mohamed, A. A. Z. Diab, and H. Rezk, "Partial shading mitigation of PV systems via different metaheuristic techniques," Renewable energy, vol. 130, pp. 1159-1175, 2019.

[33] M. E. E. Mahmoud, M. K. Ahmed, A. A. Z. Diab, and B. M. Hasaneen, "Modelling and simulation of photovoltaic array fed induction motor based on field oriented control and single stage MPPT inverter for water pumping system," cell, vol. 11, pp. 13-15, 2017.

[34] T. Esram and P. L. Chapman, "Comparison of Photovoltaic Array Maximum Power Point Tracking Techniques," IEEE Transactions on Energy Conversion, vol. 22, no. 2, pp. 439-449, 2007/06 2007, doi: $10.1109 /$ tec.2006.874230.

[35] I. K. Bousserhane, "Direct Field-Oriented Control Design using Backstepping Technique for Induction Motor Speed Control," presented at the $200614^{\text {th }}$ Mediterranean Conference on Control and Automation, 2006/12, 2006. [Online]. Available: http://dx.doi.org/10.1109/med.2006.234901.

[36] A. A. Z. Diab, "Robust simultaneous estimation of stator and rotor resistances and rotor speed for predictive maintenance of sensorless induction motor drives," International Journal of Power and Energy Conversion, vol. 8, no. 4, pp. 411-434, 2017.

[37] A. G. M. A. Aziz, A. A. Z. Diab, and M. Abd El Sattar, "Speed sensorless vector controlled induction motor drive based stator and rotor resistances estimation taking core losses into account," in 2017 Nineteenth International Middle East Power Systems Conference (MEPCON), 2017: IEEE, pp. 1059-1068.

[38] A. A. Zaki Diab, D. A. Kotin, V. N. Anosov, and V. V. Pankratov, "A comparative study of speed control based on MPC and PI-controller for Indirect Field oriented control of induction motor drive," presented at the 2014 12th International Conference on Actual Problems of Electronics Instrument Engineering (APEIE), 2014/10, 2014. [Online]. Available: http://dx.doi.org/10.1109/apeie.2014.7040781.

[39] Datasheet of LORENTZ PS9k2 C-SJ42-4, "http://kgelectric.co.za/assets/product_docs/lorentz/sub mersibles/datasheets/PSk2/LORENTZ_PS9k2_c-sj424 _pi_en_ver301051.pdf."

Conflicts of Interest: The authors declare no conflicts of interest.

Funding: 'Not applicable'

Contributions: All authors contribute to output this paper in this form.
Appendix I:

\begin{tabular}{|c|c|}
\hline \multicolumn{2}{|l|}{ PV module Parameter } \\
\hline Parameter & Values \\
\hline Ns & 36 \\
\hline Isc (A) & 8.93 \\
\hline Voc(V) & 22.66 \\
\hline Current at MPP, Imp (A) & 8.25 \\
\hline Voltage at MPP, $\mathrm{Vmp}(\mathrm{V})$ & 17.54 \\
\hline $\mathrm{Io} 1=\mathrm{Io} 2(\mathrm{~A})$ & $2.04667641 \mathrm{e}-10$ \\
\hline $\operatorname{Rp}(\Omega)$ & 129.520708 \\
\hline $\operatorname{Rs}(\Omega)$ & 0.30 \\
\hline
\end{tabular}

\begin{tabular}{|l|l|}
\hline \multicolumn{2}{|l|}{ PV array data } \\
\hline Voltage at MPP, Vmp_array(V) & $614 \mathrm{~V}$ \\
\hline Current at MPP, Imp_array (A) & $16.5 \mathrm{~A}$ \\
\hline Power at MPP, Pmp_array(W) & $10 \mathrm{KW}$ \\
\hline Nser (No. of modules connected in series) & 35 \\
\hline Npar (No.of modules connected in parallels) & 2 \\
\hline
\end{tabular}

\begin{tabular}{|l|l|}
\hline \multicolumn{2}{|l|}{ Parameters of Induction motor } \\
\hline Nominal power & $7.5 \mathrm{~kW}$ \\
\hline Nominal line-to-line voltage & $400 \mathrm{~V}$ \\
\hline Nominal frequency & $50 \mathrm{~Hz}$ \\
\hline Stator resistance and inductance & $\begin{array}{l}0.7384 \Omega, \\
0.003045 \mathrm{H}\end{array}$ \\
\hline Rotor resistance and inductance & $0.7402 \Omega$, \\
& $0.003045 \mathrm{H}$ \\
\hline Mutual inductance & $0.1241 \mathrm{H}$ \\
\hline Number of pole pairs & 2 \\
\hline
\end{tabular}

